\title{
Butterfly range extensions in the Philippines and Indonesia
}

\section{Jade Aster T. Badon' ${ }^{1}$ and David J. Lohman ${ }^{2,3,4}$}

\begin{abstract}
Recent curation of the butterfly collections in the National Museum of Natural History in Manila, Philippines, and the McGuire Center for Lepidoptera and Biodiversity, Florida Museum of Natural History, University of Florida, USA, resulted in new island records of Ideopsis juventa luzonica (Nymphalidae: Danainae) from Mabog Island in the Babuyan Islands, Philippines, Cheritra freja pallida (Lycaenidae: Theclinae) from Sebuku Island, Borneo, and Eurema hiurai (Pieridae: Coliadinae) in Zambales (Luzon) and Cotabato (Mindanao), Philippines.
\end{abstract}

Keywords: butterflies, range, Philippines, Indonesia

The Philippines is a megadiverse biodiversity hotspot (Mittermeier et al. 1997; Myers et al. 2000). The archipelago has more than 7,100 islands and a complex geologic history that has contributed to generating its incredible species richness (Brown et al. 2013). Even small islands can have high species diversity (Jonsson and Holt 2015; Li et al. 2017). Unlike most other tropical countries, the geographic distributions of the Philippines' $900+$ butterfly species are well documented, thanks to decades of work by Colin 'Trig' Treadaway and his collaborators (Treadaway and Schroeder 2012). Nonetheless, while curating the butterfly collections of the National Museum of Natural History (Manila, Philippines) and the McGuire Center for Lepidoptera and Biodiversity (Gainesville, Florida, USA), we found several specimens that expand the known ranges of their species.

Ideopsis juventa luzonica was described as Radena luzonica by Moore in 1883 from type material collected in northern Luzon. The island from which the type specimen was

${ }^{1}$ Biology Department, Silliman University, Dumaguete City,
Philippines 6200 and The Philippine Lepidoptera Butterflies and
Moths, Inc.
${ }^{2}$ Biology Department, The City College of New York, The City
University of New York, New York, NY 10031, USA
${ }^{3}$ Ph.D. Program in Biology, Graduate Center, The City University of
New York, New York, NY 10016, USA
${ }^{4}$ Entomology Section, National Museum of Natural History, Manila,
Philippines 1000
*Corresponding email: jadetbadon@su.edu.ph
Date Submitted: 15 December 2019
Date Accepted: 27 May 2020

(C) Association of Systematic Biologists of the Philippines collected is not known, but D'Abrera (1982) and Yata and Morishita (1985) inferred that it was one of the islands in the Babuyan Islands. The distribution of $I$. juventa luzonica recorded by Treadaway and Schroeder (2012) is listed as the Babuyan and the Batanes Islands, which are small island groups. It is possible that the first or all of the specimens of $I$. juventa luzonica were collected on a single island: Babuyan Island.

\section{New island records}

Ideopsis juventa luzonica (Moore 1883)

Previously recorded subspecies distribution: Babuyan and Batanes Islands (Treadaway and Schroeder 2012)

Range extension: Mabog Island (Babuyan Islands). V. Samarita, leg. 3/11/1990 (Figure 1g-h)

Specimen repository: National Museum of Natural History, Philippines

\section{Cheritra freja pallida (H. Druce 1873)}

Previously recorded subspecies distribution: Borneo, Pulau Laut, Karimata (Seki et al. 1991)

Range extension: Sebuku island (an island east of Pulau Laut). According to Yusuke Takanami (pers. comm.), the newly recorded specimens are either a dry season form or collected from an arid habitat (Figure 2a-b).

Specimen repository: McGuire Center for Lepidoptera and Biodiversity, Florida Museum of Natural History, University of Florida, Florida, USA

Eurema hiurai Shirozu \& Yata 1977 is endemic to the Philippines and has three described subspecies: E. h. admiranda 


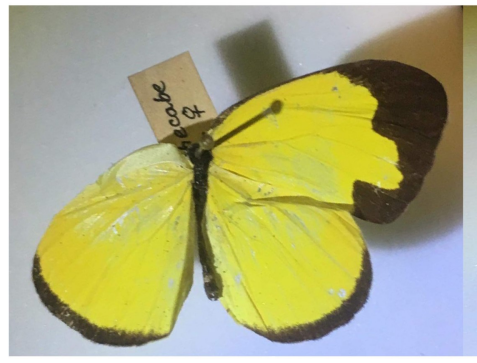

(a)

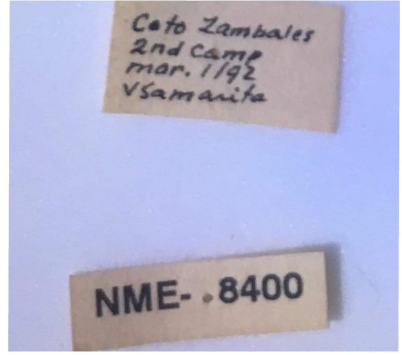

(c)

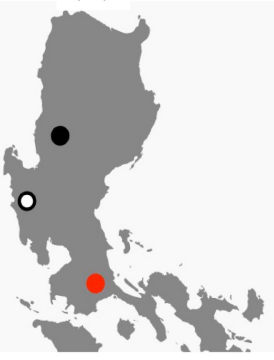

(e)

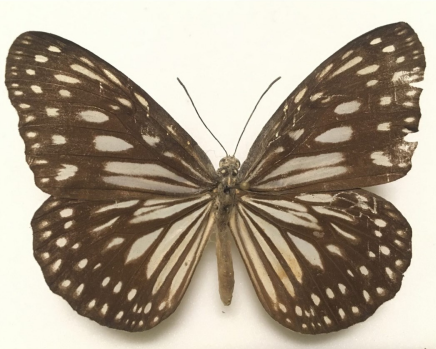

(g)

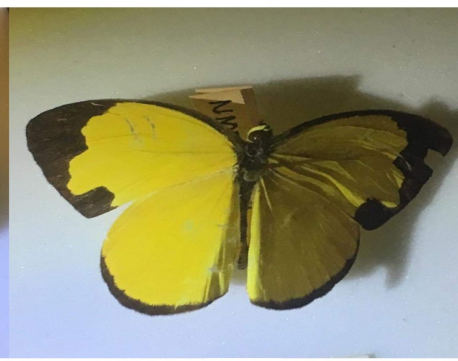

(b)

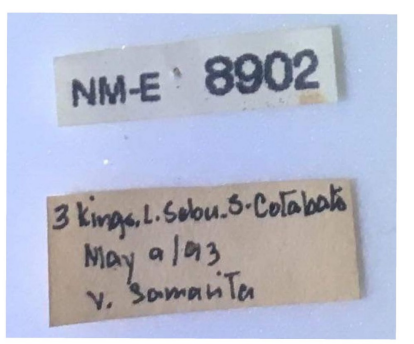

(d)

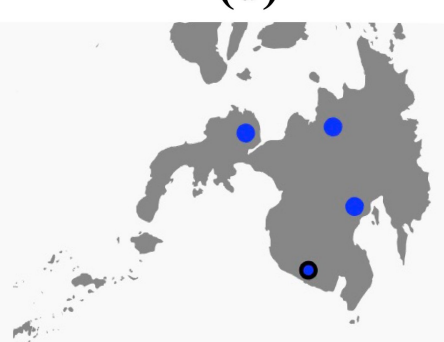

(f)

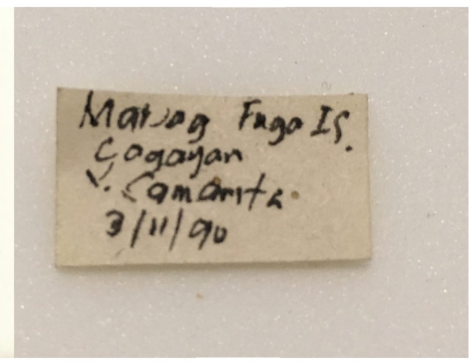

(h)

Figure 1. (a) Eurema hiurai admiranda ふ̋; Zambales, Luzon, (b) Eurema hiurai hiurai ${ }^{\uparrow}$; Cotabato, Mindanao. (c) Museum labels of E. hiurai admiranda, (d) Museum labels of E. hiurai hiurai, (e) Some collection localities of Eurema hiurai admiranda in Luzon. The black circle indicates the locality where $E . h$. admiranda was first collected, while the white circle with black outline indicates the range extension. The red circle indicates the first collection locality of E. h. banahawensis, (f) Some collection localities of E. h. hiurai in Mindanao. Blue circles are based on previous publications, while the blue circle with the black outline indicates the range extension, (g) Ideopsis juventa luzonica 우, (h) Museum label of I. j. luzonica

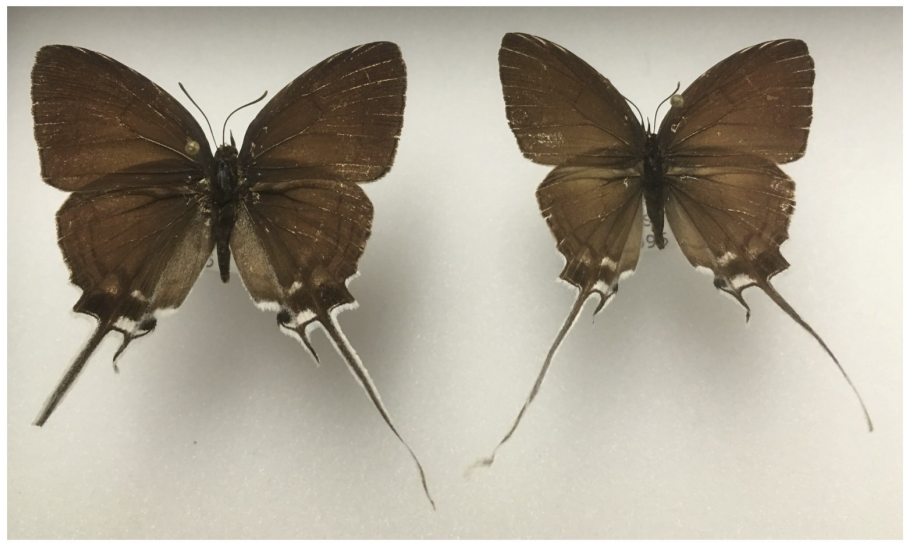

(a)

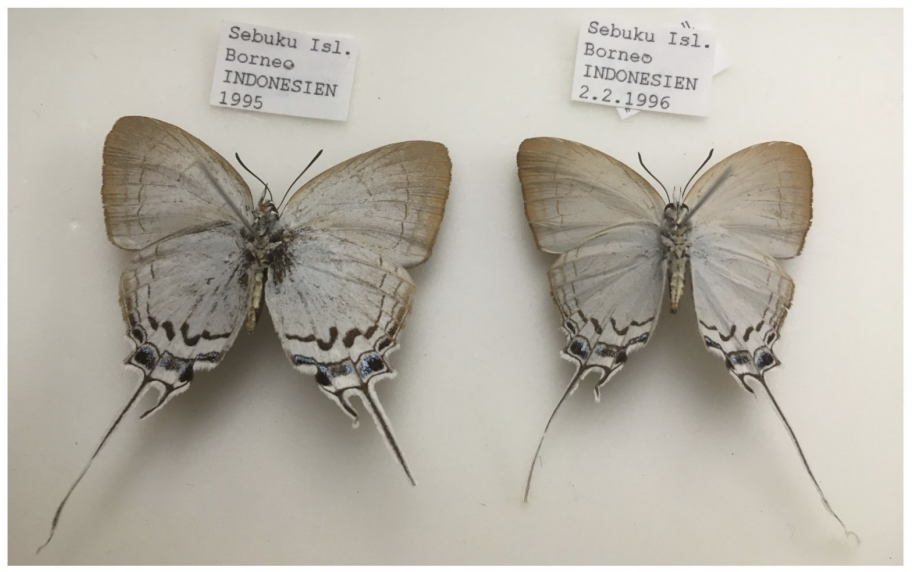

(b)

Figure 2. (a) Cheritra freja pallida; upperside, and b) C.f. pallida underside including museum labels.

Morishita 1981 in northern Luzon, E. h. banahawensis Yata \& Kitamura 1998 in southern Luzon, and the nominotypical subspecies in Mindanao. The life history of this species is still unknown (Yata 1992). The holotype of Eurema hiurai was collected on November of 1969 in Palan-Capatagan, Davao del Sur (Mindanao), and the species was described along with specimens collected from Mt. Malindang on the Zamboanga Peninsula, Calinan in Davao del Sur, and Malitbog in Bukidnon.

Venancio Samarita collected a single specimen of E. hiurai (Figure 1a-b) on May 1993 from Lake Sebu in South Cotabato (Mindanao) (Figure 1d), and another specimen on March 1992 in Zambales (Luzon) (Figure 1c). These are the southernmost record of Eurema hiurai hiurai in Mindanao and the westernmost record of Eurema hiurai admiranda in Luzon. The specimens are deposited in the National Museum of Natural History in Manila, Philippines. It is possible that this species may occur in other mountain ranges of Luzon and Mindanao. Whether future discoveries will be a new subspecies or not require further exploration and research. 
According to Yata (1992), Eurema hiurai is closely related to Eurema lacteola (Distant), and the latter species is currently distributed in Sibutu (Treadaway and Schroeder 2012) — one of the southwestern islands of the Sulu Archipelago. Eurema hiurai is currently known only from Luzon and Mindanao, and the Negros Ark Hypothesis (Badon 2018) may explain the disjunct distribution of E. hiurai on these two widely separated islands. This butterfly is rare and inhabits montane forests around $1000 \mathrm{~m}$ above sea level (Yata 1992).

\section{Range extensions}

Eurema hiurai hiurai Shirozu \& Yata 1977

Distribution: Mindanao

Previously recorded distribution in Mindanao: Mt. Malindang, Zamboanga Peninsula, Davao del Sur, and Bukidnon

Range extension in Mindanao: Lake Sebu, southwest Cotabato (Figure 1f)

\section{Eurema hiurai admiranda Morishita 1981}

Previously recorded subspecies distribution: Northern Luzon Previously recorded distribution in northern Luzon: Baguio Range extension in Luzon: Zambales (Figure 1e)

\section{Acknowledgements}

We thank Marivene R. Santos, Perry A.C. Buenavente, and Jeremy R. Barns for facilitating the use of the collection in the National Museum of Natural History. Jomar D. Hinolan and Micael G.A. Itliong assisted with curation. We are grateful to Yusuke Takanami for his comments on the specimens of Cheritra freja pallida and Andrew Warren for allowing access to the collections of the McGuire Center for Lepidoptera and Biodiversity. David J. Lohman was funded by grant DEB 1541557 from the U.S. National Science Foundation, grant WW -227R-17 from the National Geographic Society, and a Fulbright ASEAN Research Scholar Award.

\section{Literature Cited}

Badon, J.A.T., 2018. The Negros Ark: A hypothesis. The systematics and biogeography of Rhopalocera (Lepidoptera) in the Philippines. Philippine Journal of Systematic Biology, 12:52-61.

Brown, R.M., C.D. Siler, C.H. Oliveros, J.A. Esselstyn, A.C. Diesmos, P.A. Hosner, C.W. Linkem, A.J. Barley, J.R. Oaks, M.B. Sanguila, L.J. Welton, D.C. Blackburn, R.G. Moyle, A. Townsend Peterson \& A.C. Alcala. 2013. Evolutionary processes of diversification in a model island archipelago. Annual Review of Ecology, Evolution, and Systematics, 44:411-435.

D'Abrera, B., 1982. Butterflies of the Oriental Region. Part 1. Papilionidae, Pieridae \& Danaidae. Hill House, Melbourne.

Jonsson, K.A. \& B.G. Holt, 2015. Islands contribute disproportionately high amounts of evolutionary diversity in passerine birds. Nature Communications, 6(8538):1-6.

Li, Y., J. Chen, L. Jiang \& G. Qiao, 2017. Islands conserve high species richness and areas of endemism of Hormaphidinae aphids. Current Zoology, 63: 623-632.

Mittermeier, R.A., C.G. Mittermeier \& Robles Gil, P., 1997. Megadiversity: Earth's Biologically Wealthiest Nations. CEMEX, Mexico, D.F. 501 pp.

Moore, F., 1883. A monograph of Limnaina and Euploeina, two groups of diurnal Lepidoptera belonging to the subfamily Euploeinae; with descriptions of new genera and species. Part I \& Part II. Proceedings of the Zoological Society of London 1883, 253-324.

Myers, N., R.A. Mittermeier, C.G. Mittermeier, G.A.B. da Fonseca \& J. Kent, 2000. Biodiversity hotspots for conservation priorities. Nature, 403:853-858.

Seki, Y., Y. Takanami \& K. Murayama, 1991. Butterflies of Borneo (edited by K. Otsuka). Vol. 2. Lycaenidae, Hesperiidae. Tobishima, Tokyo.

Treadaway, C.G. \& H.G. Schroeder, 2012. Revised checklist of the butterflies of the Philippine islands (Lepidoptera: Rhopalocera). Nachrichten des Entomologischen Vereins Apollo, S20:1-64.

Yata, O. 1992. A revision of the Old World species of the genus Eurema Hübner (Lepidoptera: Pieridae). Part III. Description of the sari group (part). Bulletin of the Kitakyushu Museum of Natural History, 11:1-77.

Yata, O. \& K. Morishita, 1985. Butterflies of the South East Asian Islands (edited by E. Tsukada). Vol. 2: Pieridae \& Danaidae. Plapac Co., Ltd., Tokyo. 623 pp. 